\title{
The Research on the Development of China's Internet Finance
}

\author{
Qiang Yu \\ The School of Economic and management, Harbin University \\ Harbin, China \\ Yuqiang0708@163.com
}

\begin{abstract}
Since 2013, the Internet finance has become a hot financial topic in China. Internet finance has brought the huge impact and challenge to the traditional financial relying on the technological superiority of the platform and innovative products. Some people say that the Internet finance is "subversive", it will overturn the traditional financial, however, we did not agree with this point of view in this paper. This article through the analysis of development history of Internet finance, try to find out the characteristics and prospects of China's Internet finance. Our view is that it will keep a longterm competing and cooperating between Internet finance and traditional financial. Through the study of China's Internet finance development model, we can foresee the Internet finance what change and influence on the traditional financial. This is the main content in this paper.
\end{abstract}

Keywords-development; Internet finance; traditional
financial

\section{INTRODUCTION}

\section{A. Overseas Internet Finance}

The early stage of overseas Internet finance development is faster. In America, for example, the Internet development earlier than China, in the 90s, U.S. economic growth more than a quarter of all thanks to information technology, The development of computer and telecoms industry speed is twice the U.S. economic growth speed, such as Amazon, eBay, yahoo and Google are arise and thrive in the 90s. During this period, Internet companies began to gradually into the financial sector, lots of internet finance enterprises appeared. Overseas Internet finance enterprises in the early development are relatively fast, thanks to the following three advantages: (1) technical advantage of the Internet platform, (2) Flexible and low cost investment rate, and (3) good investment experience.

Depend on these advantages, the development of Internet finance enterprise is very rapid, but after development gradually slow. Internet finance enterprises lack of professional financial talent, it is difficult to develop high value-added and high yield of financial derivative products, the core competitiveness of their product is not strong. Therefore, Internet finance enterprise development to a certain degree tend to meet the bottleneck, it is difficult to further, they won't impact and threat to traditional financial enterprises.

\section{B. Internet Finance in China}

Internet finance has become a hot topic in China since 2013. But China's Internet finance is not started in 2013. The advent of Yu'E Bao was the watershed event in terms of financial innovation. China's Internet finance impact and influence on traditional financial began in 2013.

Although China's Internet finance starting late, but the development is better than America. Broadly speaking, two trends are driving growth in Internet finance in China. First ,the products and services and capital of e-commerce and other Chinese Internet companies are into the financial sector. Second, traditional financial services are migrating to the Internet. So, Internet finance and traditional finance are two important forces of financial innovation.

In fact, the advent of Internet finance in China has appeared as early as 2004.The Alipay of Alibaba established in 2004 as a third-part payment platform. Almost all big domestic commercial Banks have launched its own online bank or created its own home page and website on the Internet after 2004. The first example of the e-commerce companies cooperating with traditional financial institutions appeared in 2012,"Shanrong”platform is a collaborative project of Alibaba and China Construction Bank.

In terms of financial functions, China's Internet finance mainly includes three development model:

- Payment and settlement services,(e.g., Alipay of Alibaba, tenpay of Tencent)

- Lending and crowd funding,(e.g., Ali Microfinance, P2P lending of Renrendai )

- $\quad$ Fund management.(e.g., Taobao wealth management of Alibaba, Wechat wealth management of Tencent)

The products or service of China's Internet finance in the table below. 
Table 1. The product and service of Internet finance in China.

\begin{tabular}{llc}
\hline Company & Product/Service & Time \\
\hline Alibaba & Alipay & 2004 \\
& Ali Micorofinance & 2013 \\
& Yu’E Bao & 2013 \\
& Taobao wealth management & 2013 \\
Tencent & Tenpay & 2005 \\
Alibaba,Tencent\& & Wechat wealth management & 2014 \\
China Ping An Insurance & Zhong An Online Property & 2013 \\
Renredai & Insurance & \\
& P2P Lending Platform & 2011 \\
Commercial Banks & Shanrong of China Construction Bank & 2012 \\
& Rong-E-Gou(B2C)of Industrial and & \\
& Commercial Bank of China & 2014 \\
\hline
\end{tabular}

\section{THE OpPORTUNITIES OF INTERNET FINANCE IN CHINA}

The development of China's Internet finance face some special opportunity, is different from the US.

\section{A. Technical Advantage Brought Opportunities for Internet Finance}

Broadly speaking, China's Internet finance starting late, but it can be applied more advanced network communication technique.

1) The Mobile Internet: Though Internet development faster in the $90 \mathrm{~s}$, but is still a "fixed" Internet, people surf the Internet must be sitting in front of a computer. With the popularity of smart phones and the emergence of the mobile Internet technology, the situation has changed. We can surf the Internet by phone, anytime or anyplace. The mobile Internet is more convenient and higher viscosity of the clients. According to statistics by CNNIC, as of June 2014, China has 527 million mobile Internet users, and 623 million Internet users, the smart phone penetration rate is 44 percent.

2) Social Network Service and Instant Messenger:Social network originated from social networking sites. In China, there are several popular Social Network Sites likes YouTube or Twitter such as Qzone, RenRen and Weibo. According to the latest survey, the amount of Weibo users has reached 200 million, and this number is still increasing at incredible speed. The instant messenger in China just like QQ and Wechat of Tencent has 800 million users. By the way of social networking and instant messenger, the Internet finance can provide more efficient information service to the investors, and boost user engagement.

\section{B. The Government Support Financial Innovation}

When the Internet finance came to China, just like the advent of Yu'E Bao in 2013. China's Internet finance with the help of new channels and technological advantages, It promote the establishment of inclusive financial system in China and increase the earning of investors. At the same time, the criticism and suspicions have never stopped. But later these attitudes were proved to be wrong. The Internet finance was written into the government work report of Chinese Premier Li Keqiang. The attitude of government support was shown to us. Reflects the Chinese government firmly determined to push forward the reform of the financial and encourage financial innovation.

\section{THE COMPETITION MEANS OF INTERNET FINANCE}

With the development of Internet finance, a revolutionary and new type of finance, different from the traditional finance, the competition means of Internet finance as shown below.

\section{RiSK PREVENTION AND STRICTER REGULATION TO INTERNET FINANCE IN CHINA}

The People's Bank of China(PBoC) looks approvingly upon the Internet finance. The PBoc has called Internet finance a beneficial complement to the exiting financial system and said it improves financial efficiency through different channels than traditional finance. But financial regulation has failed to keep up with Internet finance's rapid growth. Some risks of Internet finance are already emerging. The most urgent problem is the risk prevention and standard regulation.

\section{A. The Risk of Legal Loophole}

Some Internet finance enterprise does not pay attention to internal management, the ability of information security and protection is poor, has the danger of personal privacy leak , there are also some enterprise did not establish customer identification, they haven't perfected credit reporting system, criminals can easy to use platform to engage in illegal activities of money laundering; The existing legal rules have not make a clear positioning of Internet finance, Internet companies engaged in P2P lending business lacks special laws or regulations to effective business norms. P2P lending business mustn't involved in illegal fund-raising, that is the bottom line of the law. In recent years, P2P web site shut down, investors' money can't recover such events occur frequently, These cases caused huge economic losses to investors, we must through effective means of legislation to make up the defects of existing legal system.

\section{B. Stricter Regulation}

China's financial regulatory system contains $\mathrm{PBoC}$ 、 CSRC 、 CBRC 、 and CIRC. Because of the Internet financial involve currency trade, finance, insurance and other fields, therefore, need Supervisory and administrative department of regulators to coordinate and cooperate with 
each other. At present, the People Bank of China is drafting a file named The Guidance on Internet Finance and it might be released in the first half of 2015. This file will guide the healthy development of Internet finance from the Macro policy level.

From 2014, the CSRC announced a crack down on illegalities related to sales of certain funds offers high returns, and has already ordered some companies to rectify such practices. The China Bank Regulatory Commission announced to implement organization adjustment, set a department of inclusive finance, the personage inside course of study thinks that it is the beginning of financial regulation. Additionally, create the Internet Finance Industry Association, the industry association can more professional guidance and supervision to Internet finance enterprise, and also could help the companies to safeguard legal rights. The complete regulatory system of China's Internet finance include the policy support of the People Bank of China, the guidance to different types of business from CSRC 、 CBRC、 and CIRC, daily management and supervision to Internet finance enterprise from the Industry association.

\section{THE Future OF CHINA’s INTERNET FINANCE}

In this round of competition between Internet finance and traditional finance, Internet finance can be the winner because of it has the Internet technology advantage. With the rapid development of Internet technology and the regulatory environment has continuous improved, the intermediary function of financial institutions will gradually disappear. The development trend of traditional finance is networked and informatization. So the future development of Internet finance need to rely on the innovation of information technology, the traditional finance institution likes bank, insurance, securities institutions, they must adapt to Financial Informatization.

\section{A. Mobile Payment}

With the development of mobile Internet, play a central role in the Internet financial payment to get a more rapid development. Mobile payment as a fast, efficient means of payment, greatly improves the transaction efficiency, improve the convenience for businesses and consumers.Mobile payment development by leaps and bounds is huge users and on the entire Internet financial industry greatly promoted, as one of the core Internet banking payment, not only bear the original single payment function, but can with financial management, financial services, camp pin management etc. various scenarios are superimposed, so that the effect of the payment to be extended, to enable enterprises to achieve accelerated development

Internet finance use its convenience advantages, in trading subject, trading channels, user experience huge advantage and value innovation, making to the fragmentation of the financial integration, make an inventory of the stock of capital, played an obvious role in the GSP financial system. Internet banking fill the part of the blank of China's financial service industry, but also to promote the development of China's financial industry, enrich the content of China's financial industry service.

\section{B. The Core Technology of Internet Finance is Big Data}

Big Data is the latest achievement of information technology development after cloud computing and Internet of things. The technology advantage of Internet finance is Big Data and Cloud Computing. By the way , Internet finance has the ability of data collection and analysis. There are two purposes of Big Data applied in the financial sector. First, Big Data effectively alleviate the problem of information asymmetry between investors and enterprises, Internet finance can develop targeted marketing in the context of achieving accur ate marketing. For example, Through analyses the transaction records, Alibaba master the real financial status of those merchants, and to know, who need financing service, how much financing amount is necessary. Second, Big Data effectively reduces the transaction costs and financial risks. Alibaba creased the financial risk model, Real-time online monitoring by Big Data, can update the result of risk assessment, reduced the risk of bad debts. The core technology of Internet finance is Big Data.

Big Data processing abandon the traditional sea operation mode and authoritative decision-making thinking, through the data mining to find the rules, can greatly reduce the transaction costs transaction information asymmetry brings. For Internet finance, data not only make it to achieve the financial services and products innovation, user experience of change, also open the business process and management pattern of the new, had a significant impact on financial services provider organizational structure, data requirements and management, user characteristics, source of product innovation, credit and risk characteristics, and significantly increased the diversity of financial system

\section{Cloud Computing.}

Internet banking of cloud computing is the use of cloud computing model, in which the principle, the financial institutions of the washing information system architecture is transferred to the end, or is the use of the Internet to achieve interoperability of data of center, the formation of efficient data efficiency mechanism. Electricity supplier industry, the rapid development of electronic payment platform is put forward higher requirements, if there is no strong technology base, server in the face of numerous net are operating at the same time will appear response delay, plug connection, even system crash. The powerful calculation processing ability of Cloud Computing, professional information security management and good system scalability just to make up the electronic payment platform don't make online consumer more secure, reliable. 


\section{Win-win Cooperation between Internet Finance and Traditional Finance}

Internet finance and commercial banks has their own comparative advantages. The advantage of Internet financial comes from platform, retail customer resources and data source. The commercial bank has the advantage of capital, resources, credit and wholesale customers the ability to control the risk. The channel is not smooth and the information asymmetry is the main difficulty of commercial banks to make small micro enterprise and individual credit, so it is very difficult to bulk access to customers, leading to credit the high cost and low efficiency. While the high-end customers face-to-face personalized service is short board Internet Financial.

The influence of the Internet finance is huge, but it is still the financial nature. Traditional finance has the advantage of huge money and customer credit. The traditional finance has the advantage of capital cost, but Internet finance has the advantage of information technology. There's no substitute for each other. The development in future is win-win cooperation.

\section{ACKNOWLEDGMENT}

Fengge Yao is my mentor during study in Harbin University of Commerce, During Writing this paper, I got the help and guidance of professor Yao, thanks to him.

This work is supported by Harbin University Youth(master) Scientific Research Fund Project, No. HUYF2014-013.

\section{REFERENCES}

[1] Berger S and Gleisner F., "Emergence of Financial Intermediaries on Electronic Markets: The Case of Online P2P Lending" [A], Working Paper, University of Frankfurt, 2008.

[2] Chesbrough \& Rosenbloom, 2002, The Role of the Business Model in Capturing Value from Innovation: Evidence from Xerox Corporation's Technology Spin-off Companies [J], Industrial and Corporate Change,3: 125-136.

[3] David Birch, Michael A. Young. Financial services and the Internet-what does cyberspace mean for the financial services industry?Internet Research, 1997 .

[4] Dyan T. Kalina, Centralized credit interchange system of converting purchase credit awards through credit exchange system for purchase of investment vehicle, US Patent 5,970,480, 1999.

[5] Goldman Sachs, "Mobile Monetization: Does the Shift in Traffic Pay?” [R],2012.

[6] Beck T,Demirguc-Kunt A, Martinez Peria M S. Reaching out: Access to and use of banking services across countriesfJ]. Journal of Financial Economics,2007,85 (1): 234-266.

[7] Hannig A, Jansen S. Financial Inclusion and Financial Stability: Current Policy Issues[R], ADBI Working Paper No. 259,December 21,2010 .

[8] Shiller R J. Finance and the good society[M]. Princeton University Press, 2013.
[9] Kempson E, and Whyley C. Kept out or Opted out? Understanding and Combating Financial Exclusion[M]. West Sussex, Biblios Publishers: The Polity Press in Association with the Joseph Rowntree Foundation, 1999.

[10] Tomi Dahlberg, Niina Mallat,Jan Ondrus, Agnieszka Zmijewska. Past, present and future of mobile payments research: A literature review[J]_Electronic Commerce Research and Applications, 2008, 7 (2):165-181.

[11] Chakrabarty K C. Financial Inclusion and Banks: Issues and Perspectives[J]. RBI Bulletin, 2011,12 (4): 1831-1838.

[12] Beck T, Demirgu^-Kunt A, Peria M S M. Banking services for everyone? Barriers to bank access and use around the world[J]. The World Bank Economic Review, 2008,22(3): 397-430.

[13] Ivatury G. Using technology to build inclusive financial systems[M]. NewPartnerships for Innovation in Microfmance. Springer Berlin Heidelberg, 2009: 140-164.

[14] Tang M. Inclusive growth and the new phase of poverty reduction in the People's Republic of China[J]. Asian Development Review, 2008,25(1-2): 81-99.

[15] Gelissen, Wim J. H., Van Oorschot, Ellen Finsveen. How Does The Welfare State Influence Individuals' Social Capital ?. European Societies, 2012; 3

[16] Badertscher,B.A.,Burks,J.J,and Easton.P.D.2012. A convenient Scapegoat: Fair value Accounting by Commercial Banks during the Financial Crisis [J]. The Accounting Review, 87(1),59-90.

[17] Berger S and Gleisner F., "Emergence of Financial Intermediaries on Electronic Markets: The Case of Online P2P Lending" [A],Working Paper, University of Frankfurt, 2008.

[18] Merton. On the Application of the Continuous-time Theory of Finance to Financial Intermediation and Insurance [J] Journal of Political Economy,2009(14):225-261. 